\title{
Cognitive impairment and associated factors among institutionalized elderly persons in Natal, Rio Grande do Norte, Brazil
}

\author{
Fabienne Louise Juvêncio Paes de Andrade' \\ Joelmma Maria Rebouça de Lima² \\ Kalyne do Nascimento Moreira Fidelis ${ }^{2}$ \\ Javier Jerez-Roig' \\ Kenio Costa de Lima'
}

\section{Abstract}

Objective: To identify the prevalence of cognitive impairment and associated factors among institutionalized elderly persons. Methods: A cross-sectional study was conducted from October to December 2013 in Long-Term Care Facilities for the elderly in Natal, Rio Grande do Norte, Brazil, featuring 326 elderly persons of both genders. The assessment of cognitive decline was classified using the Pfeiffer test. Information on sociodemographic conditions and health status was also recorded. Nutritional status was assessed by applying the Mini Nutritional Assessment tool and functional capacity with the Katz Index. To identify the factors associated with the presence of moderate or severe cognitive impairment multiple logistic regression analysis of variables with a $p$ value $\geq 0.20$ was performed, using the Stepwise Forward method. Results: It was observed that 83.6\% (95\% CI: 78.9 to $87.3 \%$ ) of the elderly persons had cognitive impairment. The final model, adjusted for type of LTCF, showed that being 83 years old or older was considered a risk factor for moderate or severe cognitive impairment. However, having systemic arterial hypertension ( $\mathrm{SAH}$ ) and having been institutionalized through their own choice were considered protective factors for moderate or severe cognitive impairment. Conclusion: the variables age, having SAH and having been institutionalized through their own choice are directly associated, as risk or protection factors, with the presence of severe or moderate cognitive impairment of the elderly population. The early diagnosis of these factors can lead to greater focus in setting goals for prevention and health care, thus improving the quality of life of these individuals.

\footnotetext{
Universidade Federal do Rio Grande do Norte, Programa de Pós-Graduação em Saúde Coletiva Departamento de Odontologia. Natal, RN, Brasil.

2 Universidade Federal do Rio Grande do Norte, Departamento de Fisioterapia. Natal, RN, Brasil.
}

\section{Correspondence}

Fabienne Louise Juvêncio Paes de Andrade

E-mail: fabi.louise@gmail.com
Keywords: Health of Institutionalized Elderly. Homes for the Aged. Frail Elderly. Cognitive Aging. Cross-Sectional Studies. 


\section{INTRODUCTION}

The rapid growth of the elderly population serves as a warning to the Brazilian government about the need to create public policies that will prepare society for this reality. Another consequence of the growth in the number of elderly people is the increased prevalence of chronic-degenerative diseases and the modification of the epidemiological profile of morbidity and mortality of the population, resulting in an overburdening of health services for the elderly and negative social and economic consequences for public health ${ }^{1}$.

The aging process is characterized by the impaired functioning of all bodily systems, with the Central Nervous System one of the most affected due to the development of disorders in the neurotransmitter system and cerebral hypotrophy. These changes tend to occur in the regions responsible for cognitive functioning and, consequently, minimum to significant impairments of such functioning are common among elderly individuals ${ }^{2}$ During the aging process, $15 \%$ of people initially develop progressive cognitive impairment. Of this number, approximately 5\% of those over 65 and $20 \%$ of those older than 80 develop moderate to severe dementia ${ }^{3}$.

Cognition involves the entire sphere of mental functioning and includes the ability to feel, think, perceive, remember, reason, form complex structures of thought, and to produce responses to external demands and stimuli ${ }^{4}$. Some factors, such as socioeconomic, psychological and health-related issues, may contribute to the gradual decline of cognitive functions ${ }^{5}$.

The changes and deficits caused by this loss in cognition have direct consequences on the quality of life of the elderly, which can lead to functional decline and the decrease and/or loss of the capacity to perform activities of daily living (ADL). Both physical and mental diseases can lead to the loss of independence and autonomy, which are important risk factors for mortality ${ }^{6}$.

For the elderly, the loss of the ability to perform ADLs is not only a risk for mortality, but also, in many cases, a predictor of institutionalization. According to Maseda et al. ${ }^{7}$, among the main predictors of institutionalization are a low frequency of living with relatives and friends and increased age.

The diagnosis of the cognitive profile of elderly persons provides long-term care facilities for the elderly (LTCFs) with important information to plan and guide the individualized care of those with a certain degree of dependence, as well as allowing the possibility of adding resources to maintain such elderly persons as active as possible by setting objective goals, such as the training of caregivers, and designing therapies to improve the quality of life of the elderly ${ }^{8}$.

Thus, the identification of the health conditions of the elderly, as well as their cognitive status, can contribute to establishing of goals that allow greater care and support for this population, contributing to a better quality of life and reducing institutionalization caused by a lack of autonomy and independence. Thus, the objective of the present study was to identify the prevalence of cognitive impairment and its associated factors in institutionalized elderly persons.

\section{METHOD}

A cross-sectional study was carried out between October and December 2013. All elderly persons aged 60 years old or more and residing in private or non-profit LTCFs in the city of Natal, in the state of Rio Grande do Norte, Brazil were included in the study. Of the 14 LTCFs registered with the Sanitary Surveillance Service in the city of Natal, Rio Grande do Norte, ten $(71.4 \%)$ agreed to participate in the study, five of which were private and five of which were non-profit. Elderly persons who were not present at the LTCFs due to hospitalization, as well as those residents with hearing loss or who did not speak Portuguese, were in a terminal condition, a coma or under palliative care were excluded from the study.

The dependent variable of the study was the presence/absence of cognitive impairment, classified through the Pfeiffer Test, which evaluates long-term and short-term memory, orientation, information about daily tasks and mathematical ability. This instrument allows the classification of the elderly into the categories intact mental function, or mild, moderate or severe cognitive impairment, taking into account the schooling of the individual evaluated'. 
For each elderly person, information on sociodemographic conditions (age, gender, education, marital status, children, type of LTCF, reason for institutionalization, resident per caregiver, retired and health plan) and health status (chronic diseases, history of falls in the last 30 days, mobility, functional capacity, daily use and number of drugs). Nutritional status was evaluated through the application of the Mini Nutritional Assessment (MNA) tool. This instrument is divided into four parts: anthropometric evaluation [Body Mass Index (BMI), arm circumference, calf circumference and weight loss]; overall assessment (questions related to lifestyle, medication, mobility and psychological problems); dietary assessment (questions related to number of meals, food and liquid intake, as well as autonomy in food); and self-assessment (selfperception of health and nutritional status). The sum of the MNA scores classified the elderly into three distinct groups: individuals with adequate nutritional status (MAN $\geq 24$ ), at risk of malnutrition ( $\mathrm{MAN} \geq 17$ and $<24)$; and with malnutrition (MAN <17).

Functional capacity was assessed using the Katz Index, an instrument validated for Brazil, which contains six Basic Activities of Daily Living (BADL): bathing, dressing, toileting, transferring, continence and feeding ${ }^{10}$. For the evaluation of transferring the states of walking without help, walking with help, wheelchair users and being bedridden were considered. Such information was obtained from medical records or was provided by staff of the institutions (social workers, nursing technicians or caregivers).

The present study is part of a project entitled "Human Aging and Health - the reality of institutionalized elderly persons in the city of Natal, Rio Grande do Norte", approved under opinion number 308/2012 of the Comité de Ética em Pesquisa (the Research Ethics Committee) (CEP) of the Universidade Federal do Rio Grande do Norte (the Federal University of Rio Grande do Norte) (UFRN). Residents and direct caregivers of the LTCFs who agreed to participate in this research project signed corresponding Free and Informed Consent Forms (FICF).

The research team was composed of two doctorate students from the post-graduate program in Public Health of UFRN and 18 undergraduate students in Physiotherapy at UFRN, who were properly trained to use the instruments. Meetings were held prior to the beginning of the data collection to explain the research project and the objectives of the work. Afterwards, training was carried out with the data collection instruments, especially with the application of the questionnaires, aiming to ensure uniformity of the understanding and application of the criteria evaluated in the study. The pilot study was conducted in two of the non-profit LTCFs. Twenty-five questionnaires were used to thoroughly review the information collected and detect possible biases, lost or discordant data.

Descriptive analysis, through the presentation of absolute and relative values, was used to analyze the data. The quantitative variables were described by means, with standard deviation $(\underline{ \pm} \mathrm{sd})$ and later categorized into dichotomous variables by the median. Bivariate analysis was subsequently performed using the Chi-squared test (or Fisher's Test) for nominal categorical variables. The magnitude of the association was verified by the odds ratio for each of the independent variables in relation to the dependent variable.

In order to identify the factors associated with the presence of moderate or severe cognitive impairment, a multiple logistic regression analysis of the variables with a $p$ value equal to or less than 0.20 was performed using the Stepwise Forward method. The permanence of the variable in multiple analysis was based on the Likelihood Ratio Test and the absence of multicollinearity, as well as its ability to improve the model through the Hosmer-Lemeshow Test. The variables physical inactivity, immobility, functional disability, falls, urinary and fecal incontinence were not tested in the multiple analysis due to a causality relationship with the dependent variable. A level of significance of $5 \%$ was adopted.

\section{RESULTS}

Of the 14 LTCFs registered with Vigilância Sanitária (Sanitary Surveillance Service) (VISA) in the city of Natal, Rio Grande do Norte, ten (71.4\%) LTCFs accepted to participate in the study. Of the total number of elderly persons $(\mathrm{n}=326)$, ten $(3.0 \%)$ individuals were excluded from the study: four $(1.2 \%)$ of whom were hearing impaired or did not speak 
Portuguese, four $(1.2 \%)$ of whom were hospitalized during the data collection period, one $(0.3 \%)$ of whom was in a terminal phase of life and one $(0.3 \%)$ of whom was under 60 years of age. In addition, 12 $(3.7 \%)$ refused to participate. Thus, the total sample consisted of 304 individuals, most of whom were female $(76.6 \%)$, with a mean age of 81.4 years $(\mathrm{sd} \pm 8.9)$. Most of the residents lived in non-profit institutions, were retired, single, illiterate or had an Elementary School I education, and had no health plan. It was found that $50.5 \%$ of the elderly persons had children and the mean residence time at the LTCF was 60.4 months (sd \pm 57.9 ). There were on average 8.0 residents per caregiver $(\mathrm{sd} \pm 5.1)$ in institutions.

Regarding health status, $81.6 \%$ did not perform physical activity, $41.0 \%$ presented a risk of malnutrition, $37.2 \%$ walked without help, and $26.3 \%$ had total functional dependence. It was verified that $88.2 \%$ of the residents had chronic diseases and $6.6 \%$ had suffered falls in the previous 30 days. The use of medication was present in $95.4 \%$ of the individuals and the average number of medications per elderly person was 4.5 (sd \pm 2.8 ). It was observed that $83.6 \%$ (95\%CI: 78.9-87.3) of the elderly persons had moderate or severe cognitive impairment.

Table 1 shows the other sociodemographic and health-related characteristics.

Table 2 contains the independent variables with a value equal to or less than 0.20 , as tested in the multiple analysis, but which were not included in the final model.

Table 1. Characteristics of participating elderly persons ( $\mathrm{n}=304)$. Natal, Rio Grande do Norte, 2013.

\begin{tabular}{|c|c|}
\hline Characteristics & $\mathrm{N}(\%)$ \\
\hline \multicolumn{2}{|l|}{ Gender } \\
\hline Male & $71(23.4)$ \\
\hline Female & $233(76.6)$ \\
\hline \multicolumn{2}{|l|}{ Age (years) } \\
\hline $60-69$ & $35(11.5)$ \\
\hline $70-79$ & $87(28.6)$ \\
\hline $80-89$ & $129(42.2)$ \\
\hline 90 or more & $53(17.7)$ \\
\hline \multicolumn{2}{|l|}{ Schooling } \\
\hline Illiterate & $71(23.4)$ \\
\hline Literate & $5(1.6)$ \\
\hline Elementary I & $70(23.0)$ \\
\hline Elementary II & $23(7.6)$ \\
\hline High School & $41(13.5)$ \\
\hline Higher Education & $44(14.5)$ \\
\hline Could not answer & $50(16.4)$ \\
\hline \multicolumn{2}{|l|}{ Marital Status } \\
\hline Single & $143(47.0)$ \\
\hline Married & $38(12.5)$ \\
\hline Divorced & $33(10.9)$ \\
\hline Widowed & $79(26.0)$ \\
\hline Could not answer & $11(3.6)$ \\
\hline \multicolumn{2}{|l|}{ Retired $*$} \\
\hline No & $14(4.6)$ \\
\hline Yes & $289(95.4)$ \\
\hline \multicolumn{2}{|l|}{ Children* } \\
\hline No & $147(49.5)$ \\
\hline Yes & $150(50.5)$ \\
\hline \multicolumn{2}{|l|}{ Type of Institution } \\
\hline Private/for profit & $113(37.2)$ \\
\hline Non-profit & $191(60.8)$ \\
\hline
\end{tabular}


Continued from Table 1

\begin{tabular}{|c|c|}
\hline Characteristics & $\mathrm{N}(\%)$ \\
\hline \multicolumn{2}{|l|}{ Reason for being institutionalized } \\
\hline Lack of caregiver & $143(47.0)$ \\
\hline Lived alone & $41(13.5)$ \\
\hline Lack of housing & $11(3.6)$ \\
\hline Illness & $36(11.9)$ \\
\hline Own choice & $8(2.6)$ \\
\hline No job & $1(0.3)$ \\
\hline Other reasons & $26(8.6)$ \\
\hline Number of reasons & $27(8.9)$ \\
\hline Could not answer & $11(3.6)$ \\
\hline \multicolumn{2}{|l|}{ Health plan* } \\
\hline No & $116(38.3)$ \\
\hline Yes & $187(61.7)$ \\
\hline \multicolumn{2}{|l|}{ Physical activity } \\
\hline No & $248(81.6)$ \\
\hline Yes & $56(18.4)$ \\
\hline \multicolumn{2}{|l|}{ Body Mass Index* } \\
\hline Underweight & $132(49.4)$ \\
\hline Eutrophic & $69(25.9)$ \\
\hline Overweight & $66(24.7)$ \\
\hline \multicolumn{2}{|l|}{ Nutritional State (Mini Nutritional Assessment)* } \\
\hline Malnutrition & $72(25.0)$ \\
\hline Risk of malnutrition & $118(41.0)$ \\
\hline Eutrophic & $98(34.0$ \\
\hline \multicolumn{2}{|l|}{ Mobility } \\
\hline Bedridden & $63(20.7)$ \\
\hline Wheelchair & $65(21.4)$ \\
\hline Walk with help & $63(20.7)$ \\
\hline Walk without help & $113(37.2)$ \\
\hline \multicolumn{2}{|l|}{ Functional capacity } \\
\hline Grade A - Independent & $76(25.0)$ \\
\hline Grade B - Independent, except one & $22(7.2)$ \\
\hline Grade C - Independent, except bathing and other & $7(2.3)$ \\
\hline Grade D - Independent, except bathing, dressing and other & $9(3.0)$ \\
\hline Grade E - Independent, except bathing, dressing, except bathing, dressing, toileting and other & $17(5.6)$ \\
\hline Grade F - Independent, except bathing, dressing, toileting, transferring and other & $70(23.0)$ \\
\hline Grade G - Dependent & $80(23.3)$ \\
\hline Non-classifiable & $23(7.6)$ \\
\hline \multicolumn{2}{|l|}{ Falls in previous 30 days } \\
\hline No & $284(93.4)$ \\
\hline Yes & $20(6.6)$ \\
\hline \multicolumn{2}{|l|}{ Chronic illnesses } \\
\hline No & $36(11.8)$ \\
\hline Yes & $268(88.2)$ \\
\hline \multicolumn{2}{|l|}{ Medication } \\
\hline No & $14(4.6)$ \\
\hline Yes & $290(95.4)$ \\
\hline \multicolumn{2}{|l|}{ Cognitive Impairment } \\
\hline Intact & $26(8.6)$ \\
\hline Mild & $24(7.8)$ \\
\hline Moderate & $64(21.1)$ \\
\hline Severe & $190(62.5)$ \\
\hline
\end{tabular}

*Missing data were not included 
Table 2. Bivariate analysis between cognitive impairment and independent variables. Natal, Rio Grande do Norte, 2013.

\begin{tabular}{|c|c|c|c|c|}
\hline \multirow[b]{2}{*}{ Variable } & \multicolumn{3}{|c|}{ Cognitive Impairment } & \multirow[b]{2}{*}{ PR (CI: 95\%) } \\
\hline & $\begin{array}{l}\text { Yes } \\
\mathrm{N}(\%)\end{array}$ & $\begin{array}{l}\text { No } \\
\mathrm{N}(\%)\end{array}$ & $p$ & \\
\hline \multicolumn{5}{|l|}{ Gender } \\
\hline $\begin{array}{l}\text { Women } \\
\text { Men }\end{array}$ & $\begin{array}{l}197(84.5) \\
57(80.3)\end{array}$ & $\begin{array}{l}36(15.5) \\
14(19.7)\end{array}$ & 0.249 & $\begin{array}{l}1.34(0.67-2.66) \\
1.00\end{array}$ \\
\hline \multicolumn{5}{|l|}{ Marital status** } \\
\hline $\begin{array}{l}\text { Without partner } \\
\text { With partner }\end{array}$ & $\begin{array}{l}206(80.8) \\
37(97.4)\end{array}$ & $\begin{array}{l}49(19.2) \\
1(2.6)\end{array}$ & $0.005^{*}$ & $\begin{array}{l}0.11(0.01-0.84) \\
1.00\end{array}$ \\
\hline \multicolumn{5}{|l|}{ Retired** } \\
\hline $\begin{array}{l}\text { No } \\
\text { Yes }\end{array}$ & $\begin{array}{l}9(64.3) \\
244(84.4)\end{array}$ & $\begin{array}{l}5(35.7) \\
45(15.6)\end{array}$ & 0.062 & $\begin{array}{l}0.33(0.10-1.03) \\
1.00\end{array}$ \\
\hline \multicolumn{5}{|c|}{ Reason for being institutionalized: did not have caregiver** } \\
\hline $\begin{array}{l}\text { Yes } \\
\text { No }\end{array}$ & $\begin{array}{l}126(88.1) \\
117(78.0)\end{array}$ & $\begin{array}{l}17(11.9) \\
33(22.0)\end{array}$ & $0.016^{*}$ & $\begin{array}{l}2.09(1.10-3.95) \\
1.00\end{array}$ \\
\hline \multicolumn{5}{|c|}{ Reason for being institutionalized: lived alone** } \\
\hline $\begin{array}{l}\text { Yes } \\
\text { No }\end{array}$ & $\begin{array}{l}29(70.7) \\
214(84.9)\end{array}$ & $\begin{array}{l}12(29.3) \\
38(15.1)\end{array}$ & $0.026^{*}$ & $\begin{array}{l}0.42(0.20-0.91) \\
1.00\end{array}$ \\
\hline \multicolumn{5}{|l|}{ Physical activity } \\
\hline $\begin{array}{l}\text { No } \\
\text { Yes }\end{array}$ & $\begin{array}{l}213(85.9) \\
41(73.2)\end{array}$ & $\begin{array}{l}35(14.1) \\
15(26.8)\end{array}$ & $0.021 *$ & $\begin{array}{l}2.22(1.11-4.44) \\
1.00\end{array}$ \\
\hline \multicolumn{5}{|l|}{ Body Mass Index** } \\
\hline $\begin{array}{l}\text { Underweight } \\
\text { Eutrophic-Overweight }\end{array}$ & $\begin{array}{l}118(89.4) \\
103(76.3)\end{array}$ & $\begin{array}{l}14(10.6) \\
32(23.7)\end{array}$ & $0.004^{*}$ & $\begin{array}{l}2.61(1.32-5.17) \\
1.00\end{array}$ \\
\hline \multicolumn{5}{|l|}{ Body Mass Index** } \\
\hline $\begin{array}{l}\text { Overweight } \\
\text { Eutrophic-Low weight }\end{array}$ & $\begin{array}{l}44(66.7) \\
177(88.1)\end{array}$ & $\begin{array}{l}22(33.3) \\
24(11.9)\end{array}$ & $<0.001 *$ & $\begin{array}{l}0.27(0.13-0.52) \\
1.00\end{array}$ \\
\hline \multicolumn{5}{|l|}{ Nutritional status** } \\
\hline $\begin{array}{l}\text { Risk of malnutrition-malnutrition } \\
\text { Eutrophic }\end{array}$ & $\begin{array}{l}158(87.3) \\
68(73.1)\end{array}$ & $\begin{array}{l}23(12.7) \\
25(26.9)\end{array}$ & $0.003^{*}$ & $\begin{array}{l}2.52(1.34-4.75) \\
1.00\end{array}$ \\
\hline \multicolumn{5}{|l|}{ Mobility } \\
\hline $\begin{array}{l}\text { Wheelchair-bedridden } \\
\text { Walk with or without help }\end{array}$ & $\begin{array}{l}121(94.5) \\
133(75.6)\end{array}$ & $\begin{array}{l}7(5.5) \\
43(24.4)\end{array}$ & $<0.001^{*}$ & $\begin{array}{l}5.58(2.42-12.89) \\
1.00\end{array}$ \\
\hline \multicolumn{5}{|l|}{ Functional Capacity } \\
\hline $\begin{array}{l}\text { Dependent } \\
\text { Independent }\end{array}$ & $\begin{array}{l}202(90.6) \\
52(64.2)\end{array}$ & $\begin{array}{l}21(9.4) \\
29(35.8)\end{array}$ & $<0.001^{*}$ & $\begin{array}{l}5.36(2.83-10.16) \\
1.00\end{array}$ \\
\hline \multicolumn{5}{|l|}{ Fall in last 30 days } \\
\hline $\begin{array}{l}\text { Yes } \\
\text { No }\end{array}$ & $\begin{array}{l}13(65.0) \\
241(84.9)\end{array}$ & $\begin{array}{l}7(35.0) \\
43(15.1)\end{array}$ & $0.030^{*}$ & $\begin{array}{l}0.33(0.12-0.87) \\
1.00\end{array}$ \\
\hline \multicolumn{5}{|l|}{ Chronic illnesses } \\
\hline $\begin{array}{l}\text { Yes } \\
\text { No }\end{array}$ & $\begin{array}{l}221(82.5) \\
33(91.7)\end{array}$ & $\begin{array}{l}47(17.5) \\
3(8.3)\end{array}$ & 0.119 & $\begin{array}{l}0.42(0.12-1.45) \\
1.00\end{array}$ \\
\hline \multicolumn{5}{|l|}{ Number of chronic illnesses } \\
\hline $\begin{array}{l}\geq 3 \\
0-2\end{array}$ & $\begin{array}{l}55(75.3) \\
199(86.1)\end{array}$ & $\begin{array}{l}18(24.7) \\
32(13.9)\end{array}$ & $0.026^{*}$ & $\begin{array}{l}0.49(0.25-0.94) \\
1.00\end{array}$ \\
\hline
\end{tabular}


Continued from Table 2

\begin{tabular}{|c|c|c|c|c|}
\hline \multirow{3}{*}{ Variable } & \multicolumn{2}{|c|}{ Cognitive Impairment } & \multirow{3}{*}{$p$} & \multirow{3}{*}{ PR (CI: 95\%) } \\
\hline & Yes & & & \\
\hline & $\mathrm{N}(\%)$ & $\mathrm{N}(\%)$ & & \\
\hline \multicolumn{5}{|l|}{ Diabetes } \\
\hline Yes & $54(75.0)$ & $18(25.0)$ & \multirow[t]{2}{*}{$0.022^{*}$} & $0.48(0.25-0.92)$ \\
\hline No & $200(86.2)$ & $32(13.8)$ & & 1.00 \\
\hline \multicolumn{5}{|l|}{ Stroke } \\
\hline Yes & $44(89.8)$ & $5(10.2)$ & \multirow[t]{2}{*}{0.139} & $1.88(0.70-5.02)$ \\
\hline No & $210(82.4)$ & $45(17.6)$ & & 1.00 \\
\hline \multicolumn{5}{|c|}{ Osteoporosis } \\
\hline Yes & $21(65.6)$ & $11(34.4)$ & \multirow[t]{2}{*}{$0.007 *$} & $0.32(0.14-0.71)$ \\
\hline No & $233(85.7)$ & $39(14.3)$ & & 1.00 \\
\hline \multicolumn{5}{|c|}{ Rheumatic Disease } \\
\hline Yes & $10(62.5)$ & $6(37.5)$ & \multirow[t]{2}{*}{$0.032^{*}$} & $0.30(0.10-0.86)$ \\
\hline No & $244(84.7)$ & $44(15.3)$ & & 1.00 \\
\hline \multicolumn{5}{|c|}{ Urinary Incontinence } \\
\hline Yes & $167(90.3)$ & $18(9.7)$ & \multirow[t]{2}{*}{$<0.001 *$} & $3.53(1.87-6.66)$ \\
\hline No & $84(72.4)$ & $32(27.6)$ & & 1.00 \\
\hline \multicolumn{5}{|c|}{ Fecal incontinence } \\
\hline Yes & $109(86.5)$ & $17(13.5)$ & \multirow[t]{2}{*}{0.181} & $1.42(0.74-2.69)$ \\
\hline No & $140(81.9)$ & $31(18.1)$ & & 1.00 \\
\hline \multicolumn{5}{|c|}{ Cardiovascular Disease } \\
\hline Yes & $14(73.7)$ & $5(26.3)$ & \multirow[t]{2}{*}{0.185} & $0.52(0.18-1.53)$ \\
\hline No & $240(84.2)$ & $45(15.8)$ & & 1.00 \\
\hline \multicolumn{5}{|c|}{ Dyslipidemia } \\
\hline Yes & $39(73.6)$ & $14(26.4)$ & \multirow[t]{2}{*}{$0.030^{*}$} & $0.46(0.23-0.94)$ \\
\hline No & $215(85.7)$ & $36(14.3)$ & & 1.00 \\
\hline \multicolumn{5}{|c|}{ Number of medications } \\
\hline$\geq 5$ & $111(79.9)$ & $28(20.1)$ & \multirow[t]{2}{*}{0.075} & $0.61(0.33-1.12)$ \\
\hline $0-4$ & $143(86.7)$ & $22(13.3)$ & & 1.00 \\
\hline \multicolumn{5}{|c|}{$\begin{array}{l}\text { Group A: medications for metabolic conditions and the } \\
\text { alimentary tract }\end{array}$} \\
\hline Yes & $130(78.8)$ & $35(21.2)$ & \multirow[t]{2}{*}{$0.013^{*}$} & $0.46(0.24-0.88)$ \\
\hline No & $121(89.0)$ & $15(11.0)$ & & 1.00 \\
\hline Group C: & & & & \\
\hline Yes & $141(78.8)$ & 38 (21.2) & $0.006^{*}$ & $0.40(0.20-0.81)$ \\
\hline No & $110(90.2)$ & $12(9.8)$ & & 1.00 \\
\hline Group H & & & & \\
\hline Yes & $20(74.1)$ & $7(25.9)$ & 0.138 & $0.53(0.21-1.33)$ \\
\hline No & $231(84.3)$ & 43 (15.7) & & 1.00 \\
\hline Group M & & & & \\
\hline Yes & $21(67.7)$ & $10(32.3)$ & $0.018^{*}$ & $0.36(0.16-0.83)$ \\
\hline No & $230(85.2)$ & $40(14.8)$ & & 1.00 \\
\hline Group N & & & & \\
\hline Yes & 201 (85.2) & $35(14.8)$ & 0.084 & $1.72(0.87-3.39)$ \\
\hline No & $50(76.9)$ & $15(23.1)$ & & 1.00 \\
\hline
\end{tabular}

${ }^{*} p \leq 0.20$ (Stepwise Forward); ${ }^{* *}$ Missing data were not included. 
The final model, adjusted for the type of LTCF, revealed that being 83 years old or older was considered a risk factor for moderate or severe cognitive impairment. However, having systemic arterial hypertension (SAH) and being institutionalized by choice were considered protective factors for moderate or severe cognitive impairment (Table 3).
The presence of collinearity was identified between the variables marital status and institutionalized due to living alone $(p<0.001)$. The variables chronic diseases, number of diseases, diabetes, number of medications, and use of group A and group C medications were collinear with SAH. The HosmerLemeshow Test value was 0.997 .

Table 3. Final model for the presence of cognitive impairment in institutionalized elderly persons $(n=304)$.

\begin{tabular}{|c|c|c|c|c|c|c|}
\hline & \multicolumn{6}{|c|}{ Cognitive impairment } \\
\hline & $\begin{array}{l}\text { Yes } \\
\mathrm{N}(\%)\end{array}$ & $\begin{array}{l}\text { No } \\
\mathrm{N}(\%) \\
\end{array}$ & $p$ & $\begin{array}{l}\text { Bivariate } \\
\text { OR (CI: 95\%) }\end{array}$ & $p$ & $\begin{array}{l}\text { Multivariate } \\
\text { OR (CI: 95\%) }\end{array}$ \\
\hline \multicolumn{7}{|l|}{ Age (years) } \\
\hline $\begin{array}{l}83 \text { or more } \\
60-82\end{array}$ & $\begin{array}{l}137(90.1) \\
117(77.0)\end{array}$ & $\begin{array}{l}15(9.9) \\
35(23.0)\end{array}$ & $0.002^{*}$ & $\begin{array}{l}2.73(1.42-5.25) \\
1.00\end{array}$ & $0.007^{*}$ & $2.62(1.30-5.29)$ \\
\hline \multicolumn{7}{|l|}{$\begin{array}{l}\text { Systemic Arterial } \\
\text { Hypertension }\end{array}$} \\
\hline $\begin{array}{l}\text { Yes } \\
\text { No }\end{array}$ & $\begin{array}{l}98(78.4) \\
156(90.2)\end{array}$ & $\begin{array}{l}33(25.2) \\
17(9.8)\end{array}$ & $<0.001 *$ & $\begin{array}{l}0.32(0.17-0.61) \\
1.00\end{array}$ & $0.001^{*}$ & $0.33(0.17-0.64)$ \\
\hline \multicolumn{7}{|l|}{$\begin{array}{l}\text { Reason for being } \\
\text { institutionalized: } \\
\text { own choice** }\end{array}$} \\
\hline $\begin{array}{l}\text { Yes } \\
\text { No }\end{array}$ & $\begin{array}{l}3(37.5) \\
240(84.2)\end{array}$ & $\begin{array}{l}5(62.5) \\
45(15.8)\end{array}$ & $0.004^{*}$ & $\begin{array}{l}0.11(0.02-0.48) \\
1.00\end{array}$ & $0.009 *$ & $0.13(0.03-0.60)$ \\
\hline \multicolumn{7}{|c|}{$\begin{array}{l}\text { Type of Long Term Care } \\
\text { Facility for the Elderly }\end{array}$} \\
\hline $\begin{array}{l}\text { Non-profit } \\
\text { Private/for profit }\end{array}$ & $\begin{array}{l}153(80.1) \\
101(89.4) \\
\end{array}$ & $\begin{array}{l}38(19.9) \\
12(10.6) \\
\end{array}$ & $0.024^{*}$ & $\begin{array}{l}0.47(0.23-0.95) \\
1.00\end{array}$ & 0.148 & $0.57(0.27-1.22)$ \\
\hline
\end{tabular}

* Statistically significant $(\mathrm{p}<0.005) ;{ }^{* *}$ Missing data was not included.

\section{DISCUSSION}

The prevalence of moderate and severe cognitive impairment was most significant, with $83.6 \%$ of the elderly persons in this study affected. This lower cognitive performance in elderly people living in LTCFs may suggest that institutionalization can aggravate this situation. In a review, Bertoldi et al. ${ }^{11}$ explained their findings with several factors which can influence cognitive deficit in institutionalized elderly people, when compared to non-institutionalized individuals, such as greater age, a low level of education, the female gender, a lack of physical activity and the social isolation caused by institutionalization itself. From data obtained in the study by Trindade et al. ${ }^{12}$, it was concluded that institutionalized elderly individuals present a lower cognitive performance, which leads to impairment of functional abilities and an increase in depression in comparison with the elderly living in society and participating in some physical activity.

The results of the present study revealed that the variable being 83 years of age or older was considered a risk factor for moderate or severe cognitive impairment. This finding was also observed in the study by Herrera et al., ${ }^{13}$ who evaluated factors associated with the cognitive functionality of elderly persons living in nursing homes in Cartagena using the Pfeiffer test, and found that the cognitive functioning of the elderly was associated with chronological age, with $80 \%$ of 192 elderly persons presenting some type of cognitive impairment. 
This decline can be explained by the fact that aging is a cumulative, irreversible, universal, nonpathological process where the body is degraded, often incapacitating the individual cognitively and functionally ${ }^{14}$. Associated with this is the fact that elderly persons living in LTCFs become increasingly sedentary, losing much of their autonomy and worsening their cognitive capacity ${ }^{15}$. This cognitive deficit directly influences functional capacity, impairing independence and autonomy with a corresponding loss of quality of life among the elderly ${ }^{16}$.

According to Mejía-Arango ${ }^{17}$, cognitive impairment is associated with increasing age as well as with various diseases. Comorbidities such as diabetes, chronic obstructive pulmonary disease (COPD), brain diseases, depression and heart disease were reported in this study, which reported the prevalence of cognitive impairment in the elderly and its relationship with demographic and health factors in a Mexican population. There was a relationship not only with cognitive, but also with functional decline. These disorders therefore represent conditions that directly affect the quality of life of the elderly and result in a greater use of health services.

It was also observed in the present study that the presence of SAH and being institutionalized by choice were considered protective factors for moderate or severe cognitive impairment. It was found that $88.2 \%$ of the institutionalized elderly presented chronic diseases, with the use of medication present in $95.4 \%$ of the individuals. In our findings, SAH was considered a protective factor for cognitive impairment. This finding can be explained by the use of antihypertensive medication, which can influence the prevention of cognitive decline due to its deleterious effects, which lead to reduced alterations in the small vessels, reducing the risk of injury to the cerebral white matter and cerebrovascular functioning ${ }^{18}$. Duron and Hanon $^{19}$, meanwhile, proposed that hypertension increases the risk not only of cognitive decline, but also of dementia. For these authors there are strong epidemiological arguments to support an association between hypertension, especially in middle age, and the development of cognitive disorders and dementia, including Alzheimer's.
These findings corroborate those of the study by Chaves ${ }^{18}$ which suggests that untreated hypertension could be a predictor for cognitive loss, with the use of antihypertensive drugs an important protector of cognition. However, studies have reached contrasting conclusions regarding the effects of antihypertensive treatment on hypertension and cognitive decline $\mathrm{e}^{20-22}$. The results of Holanda et al. ${ }^{23}$ found that hypertensive elderly individuals are at greater risk of cognitive function decline than normotensive elderly persons. Considering the changes and consequences that hypertension can cause in the elderly population, associated with cognitive disorder which can directly affect quality of life, more evidence is needed in order to prevent and treat this dysfunction as early as possible.

In relation to institutionalization, being institutionalized by choice was significantly associated with moderate or severe cognitive impairment, and was a protective factor for its occurrence. According to Cordeiro ${ }^{24}$, several reasons may lead elderly persons to choose institutionalization themselves, including living alone, considering themselves a burden or feeling rejected by the family, or being aware that they need health care. Duarte ${ }^{25}$ also mentions the reasons for the institutionalization of the elderly who, although they still have a family, prefer to live in the institution for reasons such as the lack of a spouse, the independence of children in the role of formal caretakers, and mistreatment by family members, through a more autonomous decision, not imposed by others.

In the same way, Pereira and Besse ${ }^{26}$ found that the self-institutionalized elderly had a higher level of functional independence than elderly persons who were institutionalized through the wishes of their family and those who did not have family or housing options. This finding presupposes that elderly persons who were institutionalized by choice also had a higher functional status, since cognition and functionality are directly linked. Cognitive impairment generates impairment of functional capacity for basic activities of daily living, implying the loss of independence and autonomy. This autonomy is linked to its interdependence with the integral memory related to the individual's 
capacity to take care of themselves, to perform tasks that allow them to adapt psychosocially and to be responsible for their own actions ${ }^{16}$. According to the study by Javier et al. ${ }^{27}$ which addressed the prevalence of functional disability among the institutionalized elderly, using the same sample as the present study, there was a relationship between institutionalization and the functional disability of elderly persons institutionalized due to the absence of an informal caregiver in the community. Disability explains the dependence of the elderly and their subsequent higher mortality.

Regarding the quality of life of institutionalized elderly individuals, Cordeiro ${ }^{24}$ stated that the reasons that lead to the institutionalization of the elderly can result in low levels of quality of life, due to a possible difficulty of adaptation, making them remain in the institution due to pride or health needs. On the other hand, elderly people with morbidities or those abandoned by relatives are likely to find an opportunity for a new start.

Among the limitations of the present study, the Pfeiffer Test has not yet been validated in Brazil. This instrument was used to evaluate the cognitive impairment of the present sample, due to the low complexity of the questions and its quick and easy application. In addition, the maximum amount of information possible was collected through an interview with the staff of the institutions and from medical record data, seeking to minimize underdiagnoses and underreporting.

\section{REFERENCES}

1. Ramos LR, Rosa TEC, Oliveira ZM, Medina MCG, Santos FRG. Perfil do idoso em área metropolitana na região sudeste do Brasil: resultados de inquérito domiciliar. Rev Saúde Pública. 1993;27(2):87-94.

2. Cruz DT, Cruz FM, Ribeiro AL, Veiga CL, Leite ICG. Associação entre capacidade cognitiva e ocorrência de quedas em idosos. Cad Saúde Coletiva. 2015;23(4):386-93.

3. Laks J, Rozenghal M, Engelhardt E. Sintomas psiquiátricos na doença de Alzheimer e sua relação com o estado cognitivo. Rev Bras Neurol Psiquiatr. 1995;31(5):225-34.

\section{CONCLUSION}

According to the present study, we can conclude that elderly persons tend to exhibit a high probability of moderate or severe cognitive impairment, due to the physiological changes caused by aging. Institutionalization by choice, adjusted for the type of LTCF, was considered a protective factor for cognitive deficit, as elderly persons in LTCFs are more susceptible to a sedentary lifestyle and the loss of functional and cognitive capacity. Systemic arterial hypertension, meanwhile, was identified as a protective factor, which suggests the need for more studies regarding the cognitive diagnosis of this population in order to create more specific strategies that promote healthier aging.

Cognitive impairment is therefore a subject requiring greater study, given the innumerable factors that predispose its occurrence and the growing number of elderly persons in our population. In addition, more attention must be paid to the predisposing variables of the condition in order to establish health prevention and care targets for this population, resulting in improved quality of life and reduced dependence.

\section{ACKNOWLEDGEMENTS}

The authors would like to thank the students of the Physiotherapy course of the Universidade Federal do Rio Grande do Norte who assisted with data collection.

4. Vieira EB, Koenig AM. Avaliação Cognitiva. In: De Freitas EV, Py L, editores. Tratado de Geriatria e Gerontologia. Rio de Janeiro: Guanabara Koogan; 2002. p. $921-8$

5. Canineu PR, Bastos A. Transtorno Cognitivo Leve. In: Freitas EV, Py L, editores. Tratado de Geriatria e Gerontologia. Rio de Janeiro: Guanabara Koogan; 2002. p. 128-32.

6. Gurian MBF, Oliveira RC, Laprega MR, Rodrigues Júnior AL. Rastreamento da função cognitiva de idosos não institucionalizados. Rev Bras Geriatr Gerontol. 2012;15(2):275-83. 
7. Maseda A, Balo A, Lópes LL, Fernández LL, Villamil JSR, Calenti JCM. Cognitive and affective assessment in day care versus institutionalized elderly patients: a 1-year longitudinal study. Clin Interv Aging. 2014; 9:887-94.

8. Ferreira LS, Pinho MSP, Pereira MWM, Ferreira AP. Perfil cognitivo de idosos residentes em Instituições de longa permanência de Brasília - DF. Rev Bras Enferm. 2014;67(2):247-51.

9. Martinez LJ, Duenas HR, Onis VMC, Aguado TC, Albert CC, Luque LR. Spanish language adaptation and validation of the Pfeiffer's questionnaire (SPMSQ) to detect cognitive deterioration in people over 65 years of age. Med Clín. 2001;117(4):129-34.

10. Cruz EP, Sánchez DCL, Esteves MRM. Asociación entre desnutrición y depresión en el adulto mayor. Nutr Hosp. 2014;29(4):901-6.

11. Bertoldi JT, Batista AC, Ruzanowsky S. Declínio cognitivo em idosos institucionalizados: revisão de literatura. Rev Dep Educ Fís Saúde Mest Promoç Saúde Unive Santa Cruz Sul. 2015;16(2):1-5.

12. Trindade APNT, Barboza MA, De Oliveira FB, Borges APO. Repercussão do declínio cognitivo na capacidade funcional em idosos institucionalizados e não institucionalizados. Fisioter Mov. 2013;26(2):281-89.

13. Herrera EM, Lopez ADA, Osorio DAP. Cognitive functionality of elderly residents in social protection centers in Cartagena, 2012. Indian J App Res. 2015;5:146-150.

14. Burnside IM. Enfermagem e os idosos. São Paulo: Organização Andrei; 1979.

15. Borges MGS, Rocha LR, Couto EAB, Mancini PC. Comparação do equilíbrio, depressão e cognição entre idosas institucionalizadas e não-institucionalizadas. Rev CEFAC. 2013;15(5):1073-9.

16. Abreu ID, Forlenza OV, Barros LH. Demência de Alzheimer : correlação entre memória e autonomia. Rev Psiquiatr Clín. 2005;32(3):131-36.
17. Mejía-Arango S, Miguel-Jaimes A, Villa A, RuizArregui L, Gutiérrez-Robledo LM. Deterioro cognoscitivo y factores asociados en adultos mayores en México. Salud Publica 2007;49(4):475-81.

18. Chaves AS, Santos AM, Alves MTSSB, Salgado Filho $\mathrm{N}$. Associação entre declínio cognitivo e qualidade de vida de idosos hipertensos. Rev. Bras Geriatr Gerontol. 2015;18(3):545-56.

19. E Duron, O Hanon. Hypertension, cognitive decline and dementia. Arch Cardiovasc Dis. 2008;101:81-189.

20. Di Nucci FRCF, Coimbra AMV, Neri AL, Yassuda MS. Ausência de relação entre hipertensão arterial sistêmica e desempenho cognitivo em idosos de uma comunidade. Rev Psiquiatr Clín. 2010;37(2):52-6.

21. Cavalini LT, Chor D. Inquérito sobre hipertensão arterial e décifit cognitivo em idosos de um serviço de geriatria. Rev Bras Epidemiol. 2003;6(1):7-17.

22. Posner HB, Tang X, Luchsinger J, Lantigua R, Stern $\mathrm{Y}$, Mayeux R. The relationship of hypertension in the elderly to $\mathrm{AD}$, vascular dementia, and cognitive function. Neurology. 2002; 58(8):1175-8.

23. Holanda GM, Santos CCC, Pedrosa R, Costa FA, Mendonça KMPP. Análise da função cognitiva e capacidade funcional em idosos hipertensos. Rev Bras Geriatr Gerontol. 2011;14(2):241-50

24. Cordeiro LM, Paulino JL, Bessa MEP, Borges CL, Leite SFP. Qualidade de vida do idoso fragilizado e institucionalizado. Acta Paul Enferm. 2015; 28(4):361-66.

25. Duarte LMN. O processo de institucionalização do idoso e as territorialidades: espaço como lugar? Estud Interdiscipl Envelhec. 2014;19(1):201-17.

26. Pereira FM, Besse M. Fatores associados à independência funcional de idosos residentes em instituição de longa permanência. Acta Fisiat. 2011;18(2):66-70.

27. Jerez-Roig J, De Medeiros JF, Fidélis KNM, De Lima Filho BF, De Oliveira NPD, Amaral FLJS, et al. Activity limitations in Brazilian institutionalized older people. J Geriatr Phys Ther. 2016:1. 